\title{
Why the Gilded Age ... and Why Now?
}

\author{
Charles E. Orser Jr.
}

Published online: 9 October 2012

(C) Springer Science+Business Media New York 2012

\section{Introduction}

No one who sees the cartoon can misunderstand its meaning. The image it portrays is indelible even though the author shows only a single individual, an obese man, probably in late middle age. We immediately notice that a huge pot belly protrudes over his belt line and that a tight vest stretches across his enormous chest. That he has both hands inserted firmly into his trouser's pockets only intensifies the strain on his vest. Above the $\mathrm{V}$ made by the top of his vest he, or most likely a valet, has pinned an enormous circular broach. If we look closely enough, we can see a tiny bowtie peaking out from under what should be his chin. But oddly, his chin is missing and his head has no human features. Instead, his cranium is actually a money bag embossed, not with eyes, nose, and mouth, but with a single, large dollar sign. The bag is tied at the top just where we would expect to see a tuft of hair.

This powerful image first appeared in Harper's Weekly on October 21, 1871. Its creator, the iconoclastic political cartoonist Thomas Nast, entitled it "The Brains." He meant it as a blistering caricature of "Boss" William Tweed, the front man of that quintessential wellspring of political corruption, Tammany Hall in New York City. So Nast, the man who has also given us our most recognizable image of Santa Claus, has also created a glyph of capitalist modernity and the role of money in politics that is as recognizable and as timeless an image as a Lascaux bull.

Now let's move forward 139 years to October 2010. Here we discover a new cartoon. In this one, four male figures stand in a row speaking in pairs. In the first duo, the one closest to us, a short, overweight, middle-aged man with a brush haircut and wearing a t-shirt reading "Tea Party Patriot," speaks to his companion, who wears a finely tailored three-piece business suit. The short man is telling the business man

C. E. Orser Jr. $(\bowtie)$

Department of Anthropology, New York State Museum, Albany, NY 12230, USA

e-mail: corser@mail.nysed.gov 
"Your TV ads attacking the Big Government Liberal Democrats are Great! . . But, I'm curious, who are you guys?" His companion replies "Don't worry about that little man. Just remember, we're on your side!" Behind the back of these two men and beyond their hearing, one of the men in the other pair-both of whom also wear three-piece suits - whispers to the other "Psst! Isn't he one of the chumps we laid off?" referring to the man wearing the t-shirt. This dialogue has profound meaning to many Great Recession Americans, but what is immediately remarkable about the men in the business suits is that they all have heads made of money bags embossed with a single dollar sign. Only the man in the t-shirt has a human face. The artist of this cartoon, David Horsey, entitled it "Mysterious money men behind attack ads."

The gifted artists of these two clever cartoons, separated in date by over a century, skillfully communicate trenchant social messages about their times. Among the many messages that might be revealed by these visual commentaries, two stand out most prominently. The first is that wealthy men with enormously deep pockets have the resources to control the course of events. Their heads are so filled with thoughts of financial gain and dreams of wealth that they have essentially become sacks of money. Their power and authority is betrayed by their dress, their comportment, and, at least in the second cartoon, their words. These money-bag men are comfortable being in charge. A second message contained in the cartoons, however, is perhaps the most devastating to consider. This message has at least two facets: first, that things may not have changed so much in the United States between 1871 and 2010 - men with heads of money still control the nation's economics and rule its social hierarchy - and second, that the nation has returned to a time when riches rule and those "with" do not attempt to hide their rule over those "without." Their heads of money are plainly on display and they cannot conceal it nor do they care to do so.

Both facets are true. American citizens today live in a Second Gilded Age, a time of unembarrassed condescension by the wealthy and a betrayal of the social contract by those with power, authority, and wealth. The social hierarchy remains essentially unchanged, at its grossest level, since the late nineteenth century. Our current times mirror an earlier "Age of Betrayal" (Beatty 2007). In both eras the social contract between the government and its people, if not completely severed, was at least in tatters.

Modern-world archaeologists have a special responsibility to investigate the material-social conditions of the past. Their research should cause us to reflect upon our own times and to wonder why inequality and unfair advantage still exist within a nation that unceasingly proclaims its commitment to democracy, fairness, and equality. Modern-world archaeology is a critical historical archaeology that does not attempt to deny the destructive power of voracious capitalism, the profound evils of racialization, and the perverse residues of colonialism and Eurocentrism. Its archaeology is designed to enlighten and to create paths toward a fairer world by understanding the tangible realities and hardships of the recent past. Connections between the First Gilded Age and today provide a perfect arena for such analysis.

Here I provide a context for the need for an explicit archaeology of the First Gilded Age as a way of linking our times to those of this past. This research ultimately has two entwined goals: to provide specific information about a past historical age, and by doing so, to challenge traditional historical archaeologists to think more concretely about the tangible links between the present and the past. Some may wish to see the archaeological exploration of the First Gilded Age as merely the study of a special era in the history of 
the United States, as simply another aspect of the nation's exceptionalism. This view is short-sighted because the First Gilded Age had trans-national implications. The actions and practices pursued by those in power had international ramifications, as imperialistminded capitalists sought riches and adventure outside the United States, usually in pursuit of a racialized Anglocentric agenda. This understanding, as we consider the tenacious effects of Western colonialism and imperialism, should cause us to ponder the conduct of similar practices and actions during our own time, the Second Gilded Age. The exact particulars between the two epochs may be dissimilar, but the designs behind their practices and institutions remain jarringly alike.

\section{The First Gilded Age}

Mark Twain, writing with Charles Dudley Warner, is probably most responsible for placing the term "Gilded Age" within the American consciousness. In their book, The Gilded Age: A Tale of To-Day (1873), Twain and Warner describe post-Civil War America as a political cesspool peopled with robber barons who make stock raids using inside information, elected officials who take bribes and make payoffs, and a citizenry so beaten down by injustice that it has become jaded and apathetic. Their view of late nineteenth-century America is not optimistic or favorable, but their pragmatic and realistic portrait has endured as a sagacious vision of that era. Perhaps most strangely, their picture of America is also a prescient projection from the past to today.

Historians have used various events to delineate the dates of the First Gilded Age (as do the authors of these collected papers). Here, I adopted the broadest limits, using the end of Reconstruction and the mid point of the Roaring Twenties as my boundaries. The precise dates matter far less than the activities and practices of the epoch itself. In the most favorable gloss, and in pointed contrast to Twain and Warner's vision, the Gilded Age projects a positive image of national growth, public exuberance, and economic opportunity. This was a time when Americans could believe that they and their nation were moving forward into a more glorious future. With the horrors and devastation of the Civil War fading into memory and the nation at least geographically reunited, the United States was uniquely poised to become a powerful player on the world's stage. It was a time of unlimited potential for those who "had." Their expanding opportunities and the seemingly unlimited potential for wealth really could give them metaphorical heads made of money bags.

In this positive view, Gilded Age America was also a time when those "without" could also feel a certain amount of optimism. Farm laborers could imagine greater economic stability by moving to towns and cities to become wage laborers. New technologies made travel and communication easier and faster. Even African American farmers could find collective representation in the Colored Farmer's National Alliance and Cooperative Union. In short, the "second great wave of invention" that occurred during the First Gilded Age helped to develop America's brand of capitalism. This "second revolution" gave the nation "the railroad, the steamship, and the mass production of steel" (Heilbroner 1993, p. 35).

But folded within this optimistic image of technological achievement and social advance was a growing disparity of wealth and privilege, a form of instability that appeared to be endemic to the nation's economic system. Individuals attuned to the 
nuances of this system understood that a dark undercurrent flowed beneath the veneer of wealth and advantage. For every John Jacob Astor IV there were thousands of immigrant children who would never learn to read. For every Eli Parker, the Seneca Commissioner of Indian Affairs appointed by President Grant, there were thousands of Native Americans who were made invisible in a society that worshipped the idol of Manifest Destiny. Jim Crow was not only alive and well, but he had been invited into the nation's legal code with Plessy v. Ferguson.

As is true of all history, even for a time as near to us as the First Gilded Age, the physical reality of the gap between the uppermost and the lowermost often lacks human tangibility. It seems remote and even irrelevant now. When we investigate the disparities of daily life in more detail, however, the distance between past and present narrows and we spot connections between them. Numerous contemporary accounts guide us into the realities of life in First Gilded Age America, but Lyman Horace Weeks and Jacob Riis have offered two invaluable resources for the era.

Weeks's (1898) The Prominent Families of New York is a two-volume, 636-page compilation containing several hundred short biographies of New York's most wellheeled families. This massive book contains an index with the names of over 10,500 individuals who are mentioned in the text. Weeks's title is informative, but his subtitle is even more revealing: Being an Account in Biographical Form of Individuals and Families Distinguished as Representatives of the Social, Professional, and Civic Life of New York City. His introduction divulges more:

PROMINENT FAMILIES OF NEW YORK has not been based upon, nor does it minister to aristocratic prejudices. A perusal of its pages will substantially reinforce the truth that the American colonies and the great Republic which succeeded them, have, from the outset, received a large infusion of the best blood of Europe, and that our national development owes much to such elements. The volume everywhere conveys the lesson that distinction has been gained only by public service or by usefulness in private station, and that the prosperity of the metropolis has been dependent upon its commerce and the character of its citizens in professional, mercantile, and financial life (Weeks 1898, p. 8).

Weeks explicitly denies any kind of "aristocratic" bias in compiling the book while he simultaneously extols the virtues of the "best blood" of Europe. A quick survey of the two volumes indicates, however, that the "best blood" seems to derive mostly from the Netherlands (who controlled the city from 1624 to 1664) and the English (who took control in 1664). Families of Scottish, Irish, German, and French ancestry make brief appearances, but the overall perception is that the greatness of late nineteenth-century New York City has a combined Anglo-Saxon/Anglo-Dutch foundation that took root during the colonial era. Thus, New York City's prominence overwhelming derives from its hard-working, Protestant associations.

Riis (1890), a Danish immigrant, presents a much different picture of life in the metropolis in his How the Other Half Lives. First writing an expose in Scribner's Magazine (Riis 1889), in the full text he paints vivid pictures - often doing so literally with photographs - of the opposite side of social prominence. His is a world foreign to Weeks and all those families who appear in the pages of his compendium. In Riis's world, instead of seeing opulence and advantage we perceive only squalor and despair. Here, the brightly lit palaces of the elite are replaced with dark, overcrowded 
tenements located in neighborhoods bearing the evocative names of "Hell's Kitchen," "Bandits' Roost," and "Bottle Alley." The languages spoken here have Celtic, Southern and Central European, and Middle Eastern accents. Anglo-Saxons, through present, do not dominate this world. Focusing his attention on the evils of the city's tenements, Riis (1890, p. 2) presents a description of New York that is stark and raw:

To-day three-fourths of its people live in the tenements, and the nineteenth century drift of the population to the cities is sending ever-increasing multitudes to crowd them. The fifteen thousand tenant houses that were the despair of the sanitarian in the past generation have swelled into thirty-seven thousand, and more that twelve hundred thousand persons call them home.

Riis sees the tenement as the physical embodiment of an evil system, an all-tooreal impediment diligently working to keep its families in poverty. Tenements were also a daily reminder to thousands of middle class families who desperately feared that they too might wind up there if their circumstances changed for the worst.

The images presented by Weeks and Riis - both correct, both telling - represent the Janus face of late nineteenth- and early twentieth-century America. Economic statistician Willford King (1915, p. 218-219) neatly summarizes one root cause of the problem:

there is considerable evidence to indicate that a larger fraction of the income is now concentrated in the hands of a few of the very rich than was the case twenty years ago. ... the greatest force in the last three decades making for income concentration has been the successful organization of monster corporations. The promoters and manipulators of these concerns have received, as their share of the spoils, permanent income claims, in the shape of securities, large enough to make Crœsus appear like a pauper.

\section{The Second Gilded Age}

Many people living today recognize elements of the First Gilded Age in our own times. We live in an era, much like the one observed by King and Riis, when a few families at the top of the social ladder, enjoy "a dense concentration of wealth" (Newman and Jacobs 2010 , p. 119). Since the 1970s, the richest Americans have seen their compensation rise exponentially when compared to the average full-time worker, whose income has remained flat over the same period (Piketty and Saez 2003, pp. 33-34).

Today's disparity of income, and the social advantages that accompany it, mirror those of the First Gilded Age (McHugh 2006, pp. 2-3). The precise dates of the present Gilded Age are difficult to discern with clarity (as are all historical ages) but I posit here that it properly begins with the ascent of the conservatives' supply-side economics and continues to the present day, despite the economic collapse of 200708. During the age of "Reaganomics," "the bounty for the rich from lower taxes was supposed to 'trickle down' to the rest of the American population, creating a rising tide that would lift all boats. However, in reality, it floated only a handful of yachts - filled with beautiful people flaunting Tiffany jewelry, Prada crocodile handbags $(\$ 41,000$ each) and Louboutin boots (\$2,495 at Saks)" (Parry 2011). The precepts of supply-side economics have been followed even under Democratic leadership, leading to the 
uneven amassment of fabulous wealth by a few families. Little has been left for the vast majority of Americans who cannot afford offshore bank accounts and tax havens.

The story of today's economic ascendancy, and the attitudes that accompany it, can be told by examining the life of Leo J. Hindery, Jr., a private equity fund manager, worth about $\$ 150$ million dollars. Hindery sums up his philosophy quite simply as "I think there are people, including myself at certain times in my career, who because of their uniqueness warrant whatever the market will bear" (Uchitelle 2007). The people listed in Weeks's Prominent Families of New York could not have expressed the sentiments about their "uniqueness" any better.

As Riis $(1889,1890)$ knew, wealth - its access, acquisition, and maintenancegains unique expression in architecture. Tycoons and barons built massive mansions on gigantic estates during the First Gilded Age, and many of these stand today as visible symbols of vast wealth. We can even visit some of them today and wonder at their majesty. Not to be outdone by history, real estate mogul David Siegel has provided the most flamboyant picture of Second Gilded Age exuberance in his attempt to replicate the Palace of Versailles in Windermere, Florida. His 90,000 $\mathrm{ft}^{2}$ $\left(8,361 \mathrm{~m}^{2}\right)$ house, with a $6,000 \mathrm{ft}^{2}\left(557 \mathrm{~m}^{2}\right)$ master suite, also has 13 bedrooms, 23 bathrooms, and a 20-car garage (Inskeep 2010). Siegel even rented a white tiger for his children's birthday parties (Mead 2012). For some, the acquisition of extreme wealth is consistent with their religious convictions, a social fact that resonates with the tacit message in Weeks' book:

In fact, if you keep your ears open, you can hear the praises of the rich ringing out almost everywhere. Evangelical Christianity, for example, once harbored an ancient biblical bias in favor of the poor, but now, at least in its high-profile megachurch manifestations, it has abandoned the book of Matthew for a 'prosperity gospel' that counts wealth as a mark of God's favor (Ehrenreich 2011).

Even God apparently supports the acquisition of extreme wealth to such an extent that even the word "luxury" is no longer appropriate. Clever writers have thus invented the term "hyper luxury" to describe the stratosphere of today's wealth (Socha 2011).

As was true during the First Gilded Age, however, conditions are not so rosy on the other side of the scale. The National Low Income Housing Coalition (Bravve et al. 2012, p. 7) reports that most people who need low income housing cannot afford it even while working full-time, minimum wage jobs: at fair market rent, "a renter household needs to earn at least $\$ 18.25$ per hour in order to afford a two-bedroom unit." At the current minimum wage of $\$ 7.25 / \mathrm{h}$, , a household would require three minimum-wage workers to afford the average rent. In Hawai'i, the most expensive state for rent, a minimum-wage worker would need to make $\$ 31.68 / \mathrm{h}$., while a worker in Puerto Rico, the least expensive on the list, would need $\$ 9.88 / \mathrm{h}$. In New York-the home of both Weeks and Riis - a minimum-wage earner would need to make $\$ 24.68 / \mathrm{h}$. Simply put, most Americans, even those working minimum-wage jobs, cannot afford the limited amount of housing that is now available to them. As Sheila Crowley, the President of the Coalition, noted "If you make less than (\$11.31 an hour), you can't afford modest rent" (Sieh 2002). This means, then, that a laborer in a single-worker household even in Puerto Rico cannot make rent except perhaps by working exceedingly long hours, taking in a boarder, or pooling their paychecks with other workers. 
Historians and social commentators have noted the connections between the First and Second Gilded Ages, but those who have benefitted most have only rarely confessed to noticing this linkage. An exception is offered by Sanford I. Weill, retired chairman of Citigroup, who stated "I once thought how lucky the Carnegies and the Rockefellers were because they made their money before there was an income tax. I felt that everything of any great consequence was really all made in the past. That turned out not to be true and it is not true today" (Uchitelle 2007). The modern American income tax was not present until its ratification by the required 36 states until 1913, near the end of the First Gilded Age. It seems that the super wealthy can now benefit even in the presence of a graduated income tax. Weill's net worth is reported as over $\$ 1$ billion.

\section{Why Archaeology?}

For a great number of years, archaeologists seldom perceived their labors as a social good with implications outside the narrow confines of academia. This understanding has been changing with the rise of postcolonial thinking and the greater involvement of indigenous peoples and descendant communities in archaeological practice and interpretation. In historical archaeology, modern-world archaeology openly accepts these changes. It is an archaeology specifically designed to address present-past connections: to investigate elements of today that have roots in the past, and to study things in the past that have relevance today. Modern-world archaeology is not an inward-looking antiquarianism or an empiricist particularism - what I have in the past referred to as "the size-and-shape-of-cannonballs school of historical archaeology."

I would not wish to identify any of the authors appearing in this special collection as modern-world archaeologists because that appellation must be self-applied. As is true of much well-conceptualized and thoroughly researched historical archaeology, each of their studies presents important lines of evidence that can be used to trace intriguing connections between the First Gilded Age and our own times, the Second Gilded Age.

In Christopher Barton's article, "Tacking between Black and White," we learn about the tensions that occurred in late nineteenth-century Philadelphia after the passage of the 15th Amendment to the US Constitution, ratified in February 1870. The language of Section 1 is straightforward and unmistakable: "the right of citizens of the United States to vote shall not be denied or abridged by the United States or by any State on account of race, color, or previous condition of servitude." This new law of the land, however, did not stop the violence and intimidation that kept many people of color away from the polls. Americans are quick to extol the democracy and freedoms of their nation and quick to accuse other countries of tolerating unfair voting practices. As a result, the violations of the First Gilded Age seem to represent a time when America was a much-less enlightened nation. As of this writing, however (and before the 2012 presidential election), a number of state legislators are advocating the enactment of voter suppression laws that many observers believe are directly designed to target people of color (Alter 2012). Advocates of these laws argue that citizens legally eligible to vote should be easily able to meet the new strictures. They root their propositions on the irregularities that they say have occurred in past elections. But accounts of widespread voter fraud are usually based upon anecdote, analogy, and intuition rather than empirical study (Overton 2007). Voter fraud does 
not appear to be a major problem within the United States. Even so, unsubstantiated claims of cheating can inflame the passions of partisan voters, and help to promote the kind of violence that occurred in First Gilded Age Philadelphia.

We see much the same story, albeit with different actors in a new setting, in Christopher W. Merritt, Gary Weisz, and Kelly J. Dixon's study of the Chinese laborers who built the Northern Pacific Railroad. The racism that led to inhuman working conditions was a major element of Gilded Age America, including in the West, where Asian immigrants were tasked with constructing the nation's commercial infrastructure often at the mercy of prejudiced immigrants who had arrived earlier and who had already established their place in the racial hierarchy. The "culture of inequality" Merritt and his co-authors illustrate seems from our current vantage point to be a distant feature of America's First Gilded Age, a time when the nation still perceived Chinese men and women as part of the "yellow hoard" or else idealized them as "Celestials." At the very least, we may wish to view this time as a period in America's dark history when its citizens did not trust Asians or least when they did not attempt to disguise their true feelings. As I write this, however, many neoconservatives have voiced extremely negative views of China now that its role in the world is much different than it was during America's First Gilded Age (Perkowski 2011). The relations between China and the United States are today unsettled and the United States, unlike during the First Gilded Age, no longer holds the balance of economic power and global authority. China may represent a vast new market for capitalist goods, but the flip side is that this emerging nation may also present a severe challenge to the economic hegemony of the United States.

From Jane Baxter we get a good look at the capitalist utopia of Pullman, Illinois, a place designed with paternalistic instincts equally at home in the eighteenth-century, but which, like so many utopian communities, found only strife and turmoil beneath the surface. Planned communities existed long before Pullman and they are very much still with us. Most such communities today are designed as retirement and gated communities meant to keep out the young and the boisterous or those without economic and cultural capital. One of the most famous planned communities in the United States is Celebration, Florida, the town manufactured by the Disney Corporation. This poster child for the New Urbanism was designed, for those who can afford it, around the lofty principles of homogeneity, safety, and wholesome American values. The green manicured lawns and the white picket fences, however, are merely a veneer over many residents' feelings of detachment and loss of control (Bartling 2002; Frantz and Collins 1999). The strict code of conduct to which they originally agreed has grown tiresome and confining, feelings with which Pullman's residents could undoubtedly relate.

Rebecca Graff directly confronts the creative manufacture of place seen in Pullman and Celebration in her investigation of the 1893 World's Columbian Exposition in Chicago. As she notes, any reader familiar with the bestseller The Devil in the White City is aware of how the designers of the huge complex sought to invent a world that was every bit as dreamlike as Celebration, Florida, hopes to be. In creating façades and finishes that were meant to be something they were not, the architects of the White City invented a world that consciously sought to mask and to fool; it was a vision of the world as imaginary as it was preposterous. The owners of today's McMansions seek to recreate the trick of visual manipulation of wealth and prestige that is every bit as illusory as the pillars of the Ohio Building. 
Christopher Matthews observes that the dominant elite of the First Gilded Age adopted a sense of nostalgia for a world they imagined because they feared their present. One of the profound dreads of millions of Americans of Anglo-Saxon heritage was their perceived understanding of the developing "racial impurity" of the nation's body politic. In this social projection of Chicago's White City, their racial supremacy was entangled with their perceptions of gender roles in a way that reinforced their sense of American exceptionalism. But the sense that "their" nation is special still plays a role in the American political landscape. It begins with an imagined story of the American Revolution and continues throughout the entire biased account of American history. Every difficult social problem in this telling is black and white, with the difference between good and evil being as simple as the distinction between the United States and the rest of the world. As a former Speaker of the US House of Representatives puts it, "For over 400 years, America has cultivated a singular set of vigorous virtues and habits of liberty. . . . We did so in a classically American way, with clarity and courage" (Gingrich 2011, p. 6).

In their contribution, Paul Mullins and Nigel Jeffries investigate how the ideals of the Gilded Age were brought inside the home and represented in figurines that were so commonplace and inexpensive that they could be purchased at the corner china shop or at a local fair. The First Gilded Age, though some may wish to understand it as wholly exceptional to the United States, in fact had concrete transoceanic characteristics. Symbolism could be borrowed on both sides of the Atlantic, to create socially relevant imaginations that were completely consistent with the broader racial theories of the Anglo-Saxon worldview. These inside-the-home theories were also those that gained physical expression in the White City and which can still be observed at Celebration. The expressive qualities that consumers can impress upon mass-produced commodities help them to self-define through a collective, socially relevant, class-based imagination. Physical, albeit tiny, embodiments like the "Negro Umbrella Figures" and the "Nodding Chinaman Figure" helped to sustain an imagined sense of the world that exists beyond the walls of the home. Even such tiny, seemingly insignificant objects could provide a sense of the social order.

In Paul Shackel's paper we again see the many social issues that revolved around racial assignment, prejudice, and inequality. The events around Lattimer, Pennsylvania, were synchronically unique but diachronically vibrant. The late nineteenth-century laborers he tracks faced obstacles that were unique because they involved specific individuals, actions relevant only to that place and time, and grievances that reflected the time's special circumstances. The events are also universal because they belong to the operational foundation of industrial capitalism and because the true needs of organized labor have never been fully addressed in the United States despite the strikes and massacres at Lattimer and elsewhere. Collective bargaining is as much under assault today as it was in the late nineteenth century. The Bureau of Labor Statistics (2012) reports that only $11.8 \%$ of current American workers hold union membership. New York reports the highest number of union members $(24.1 \%)$ while North Carolina enrolls the least number of unionized workers (2.9\%). A report to the US Congress shows the precipitous decline in union membership since 1945, when the high point of slightly over 35\% was reached (Mayer 2004, p. 22). The conclusion of these statistics is unavoidable: collective bargaining remains a contentious issue within the 
United States today just as it was during the First Gilded Age when workers first collectivized to create job security and safe working conditions.

\section{Conclusion}

So there we have it. Obvious connections can be discerned rather easily between the First Gilded Age and our own time, an era we can correctly term the Second Gilded Age. We make no claim that our time constitutes an example of history repeating itself. This view would be far too facile. History can never be replicated. But the conditions, rules, and limitations of a social system can be reproduced over time as an overarching structure. This stability is the reason that America's two gilded ages appear so similar.

Historical archaeologists, if they wish, can illustrate the similarities between the present and the past, but they need not do so. Each is perfectly justified to describe their research on the First Gilded Age without any reference to our present circumstances. Modern-world archaeologists, on the contrary, must necessarily make clear the connections between the present and the past. Our world is merely a continuation of an earlier world and as archaeologists of the recent past we have a special responsibility to explore the social issues that transcend time, those that are truly cemented into the social structure. The examinations of the First Gilded Age represented in this collection positively tie our own time to this earlier era, and prove that the historical actors who lived then expressed concerns and faced struggles similar to our own. Modern-world archaeology is an historical archaeology that is by definition critical and investigative; it is an archaeology that actively seeks to understand our own times by specific, concrete references to the past. For this reason, then, the archaeology of the First Gilded Age, and the way it can illustrate its many linkages to our own times, is a socially relevant archaeology. If practiced correctly, modern-world archaeology, like ethical anthropology, can be "transformative" (Price 2011, p. 3).

Acknowledgments As always, I need to acknowledge the discourse I have had with Janice Orser over the years about social justice, poverty, and inequality. More than the works of any scholar, these countless discussions have shaped my understanding of the need for an informed, socially conscious archaeology that does more than simply pay lip service to the ills of our time. I also wish to thank the authors of the papers included in this collection for their stimulating work and for their commitment to meaningful archaeology.

\section{References}

Alter, J. (2012). Republicans' voter suppression project grinds on. Bloomberg.com, June 21. <http:// www.bloomberg.com/news/2012-06-21/republicans-voter-suppression-project-grinds-on.html >

Bartling, H. E. (2002). Disney's Celebration: The promise of New Urbanism and the portents of homogeneity. Florida Historical Quarterly 81: 44-67.

Beatty, J. (2007). Age of betrayal: The triumph of money in America, 1865-1900, Knopf, New York.

Bravve, E., Bolton, M., Couch, L., and Crowley, S. (2012). Out of Reach 2012, National Low Income Housing Coalition, Washington DC.

Bureau of Labor Statistics. (2012). Union member survey. <http://www.bls.gov/news.release/union2.nr0.htm> Ehrenreich, B. (2011). Rich people are being "demonized" for flaunting their wealth. Poor dears! Washington Post, September 30.

Frantz, D., and Collins, C. (1999). Celebration, U.S.A.: Living in Disney's brave new town, Henry Holt, New York. 
Gingrich, N. (2011). A nation like no other: Why American exceptionalism matters, Regnery, Washington, DC.

Heilbroner, R. (1993). 21st Century Capitalism, Norton, New York.

Inskeep, S. (2010). Florida "fixer-upper" on sale for $\$ 75$ million. Morning Edition (National Public Radio), June 23

King, W. I. (1915). The wealth and income of the people of the United States, Macmillan, New York.

McHugh, M. (2006). The second gilded age: The great reaction in the United States, 1973-2001, University Press of America, Lanham, MD.

Mayer, G. (2004). Union membership trends in the United States, Congressional Research Service, Library of Congress, Washington, DC.

Mead, R. (2012). Housing crisis. The New Yorker 88(20): 30-32.

Newman, K. S., and Jacobs, E. S. (2010). Who cares? Public ambivalence and government activism from the New Deal to the Second Gilded Age, Princeton University Press, Princeton.

Overton, S. (2007). Voter Identification. Michigan Law Review 105: 631-681.

Parry, R. (2011). Reagan's "greed is good” folly. Consortium News, October 5. <http://consortiumnews.com/ 2011/10/05/reagans-greed-is-good-folly/>

Perkowski, J. (2011). Trump on China. Forbes, April 5. <http://www.forbes.com/sites/jackperkowski/2011/ 04/05/trump-on-china/>

Piketty, T., and Saez, E. (2003). Income inequality in the United States, 1913-1998. Quarterly Journal of Economics 118: 1-39.

Price, D. H. (2011). Weaponizing anthropology: Social science in service to the militarized state, Counterpunch, Petrolia, CA.

Riis, J. (1889). How the other half lives: Studies among the tenements. Scribner's Magazine 6: 643-663.

Riis, J. (1890). How the other half lives: Studies among the tenements of New York, Charles Scribner's Sons, New York.

Sieh, M. (2002). Decent housing out of reach. The Post-Standard (Syracuse, NY), January 24.

Socha, M. (2011). Hyper luxury: The sky's the limit. Women's Wear Daily, August 15.

Twain, M., and Warner, C. D. (1873). The gilded age: A tale of to-day, American Publishing, Hartford, CT.

Uchitelle, L. (2007). The richest of the rich, proud of a New Gilded Age, New York Times, July. 15.

Weeks, L. H. (ed.) (1898). Prominent families in New York: Being an account in biographical form of individuals and families distinguished as representatives of the social, professional, and civic life of New York City, The Historical Company, New York. 